\title{
ANALYSIS OF THE STATE OF THE LEADING SECTORS OF THE ECONOMY IN DONBAS FOR THE OLD INDUSTRIAL REGION - SUMMER-AUTUMN OF 2014
}

\author{
Elena KLYMENKO' \\ National Technical University "Kharkiv Polytechnic Institute", Ukraine
}

\begin{abstract}
The purpose of the article is to study the state of the regional industrial complex of the old industrial region of the East of Ukraine, which suffered as a result of the military-political conflict that began in 2014. One of the objectives of the study is to analyse the process of destroying the foundations of the regional economy, as well as to assess the significance of the loss of Donbas industries for the stable socio-economic development of all regions of Ukraine. Methodology. The method of analysis made it possible to study the process of destruction of industrial enterprises in the basic sectors of the regional economy of Donbas since the beginning of the military-political conflict. The author defined the schemes of the operation of a part of enterprises operating in the temporarily occupied territory of the East of Ukraine, who, becoming hostages to the situation, were forced to cooperate with representatives of the illegal authorities of the unrecognized republics to preserve production. Result. The statistical method is used to analyse the financial and economic performance of industrial enterprises, with the purpose of assessing their role in the state economy of the country as a whole. The method of system analysis allowed the author to estimate the damage caused by the loss in the state economy of coal supplies, which was previously mined in the mines of Donbas. Thus, the fact of a decrease in industrial production in the east of the country was argued, which led to a significant drop in Ukraine's exports in general in such areas as supplies of ferrous metals, engineering products, and non-ferrous metallurgy. Practical implication. The author analysed the facts of loss, as a result of dismantling and export of equipment, strategically important enterprises of the militaryindustrial complex of the country. The article reflects the problem of the growing ecological danger that has arisen as a result of the lack of control over the closed enterprises of the coal mining industry and the chemical industry. In addition, in the course of active hostilities, a number of industrial objects suffered significant damage, which leads to uncontrolled emissions of harmful substances into the atmosphere. The shutdown of mines and concentrators created yet another problem - the discharge of mine waters, their access to the surface, the flooding of significant areas and the entry of toxic waters into rivers that serve as a source of drinking water for residents, both the conflict region and the country as a whole, and neighbouring states. Also, the technogenic threat is represented by the methane gas output to the surface displaced by groundwater. Value/originality. The results of the research made it possible to depict the dynamics of the destruction of the economic complex of the old industrial region as a result of military operations in the territory of the state and illegal export of equipment of enterprises. All these actions led to the launch of negative processes in the Ukrainian economy, provoking a deep social and economic crisis, which accelerated the destruction of the metallurgical, coal and chemical industries in the region. Thus, today it is necessary to conduct an inventory of surviving and continuing enterprises, to quickly identify the risk zone, and develop strategies for minimizing and overcoming them in key sectors of the economy.
\end{abstract}

Key words: economy, ecology, export, metallurgy, coal mining, infrastructure, industry, military conflict.

JEL Classification: L60, R11, R13

\section{Introduction}

In the context of a significant change in geopolitical realities (which are accompanied by the closure of Russian markets for Ukrainian products), the search for ways and mechanisms of reforming regional economic complexes and determining the prospects for diversifying the regional economy is becoming especially important for the economy of the old industrial regions of the East of Ukraine. The successful solution of these issues depends on the prospect of achieving social and economic stability in Donbas, which has assumed all the socio-economic, political, and institutional burdens

Corresponding author:

${ }^{1}$ Department of Sociology and Political Science, National Technical University "Kharkiv Polytechnic Institute”.

E-mail: klimenkoelens@gmail.com 
caused by the changing geopolitical situation in the country. This is primarily due to the fact that in the zone of armed conflict were the traditional industrial regions of Donetsk and Luhansk regions.

In the context of intensification of crisis phenomena in the economy, it is especially necessary to develop a set of adequate actions aimed at consolidating all available resources in order to minimize negative phenomena, as well as maximize the preservation and observance of social standards in the state.

The aim of the article is to study the state of the regional industrial complex of the old industrial region of the East of Ukraine, which suffered as a result of the military-political conflict that began in 2014.

Speaking today about the definition of ways to stabilize the situation in a particular region and the country as a whole, it is important to make an inventory of the current situation of the branches of the economy and the risks that have arisen in the leading industries that have appeared in the territory of the conflict. In particular, to determine the state of the basic industries, in order to determine the feasibility of maintaining existing production facilities, the restoration of destroyed or, in general, the complete conservation of abandoned enterprises. It is also necessary to study the social component of the life of the region. In the conditions of actual occupation of a significant part of the Donetsk and Luhansk regions, the burden on the budgets of other regions is increasing, the disproportion between the demand and supply of jobs in the labour market is growing.

The political conflict of 2014 in Ukraine, thanks to the support of the pro-Russian forces, has become a trigger mechanism for unleashing a protracted military and political conflict in Donbas, which resulted in a thousand losses among civilians, over a million "temporarily displaced persons" (so-called refugees), a stagnant regional economy from key old industrial regions, breached a monolithic economic system that fills the state budget of Ukraine. An analysis of key trends in the development of the leading sectors of the economy of the old industrial region, conditioned by the ongoing military conflict between the state of Ukraine and illegal armed formations, the self-proclaimed DNR and LNR, which operate with financial and military-technical support from Russia, allows noting the following three key trends.

\section{Destruction of infrastructure}

Destruction of infrastructure led to the inhibition of economic development of settlements, a sharp impoverishment of the population and the severance of internal and external economic ties in the region. Due to the destruction of the railways, metallurgical enterprises in the region do not have the opportunity to regularly receive raw materials and materials, as well as send the already manufactured products to consumers, which implies a complete change of logistics. Over 190 railway infrastructure facilities have been damaged at the Donetsk, Pridneprovskaya and Southern railways, 49 of which are track facilities, 74 are electricity, 30 are automation and communications, and 11 are structures. According to the official data of "Ukrainian Railways", to restore the damaged railway infrastructure in the East of Ukraine at the beginning of 2015, about 900 million $\mathrm{UAH}$ is required. Footnote. Almost $75 \%$ of production facilities in Donetsk region as of December 2014 were destroyed or destroyed as a result of hostilities. In Luhansk region, 22 city-forming industrial enterprises stopped their work (Vosstanovit Donbass, 2015).

The first among the large enterprises of the region have ceased work since July 2014: Novogorovsky MachineBuilding Plant, Machine-Building Plant "Betonmash", PJSC “Luganskteplovoz”, Alchevsk Metallurgical Plant, Stakhanov Ferroalloy Plant, LLC "Stal”, PJSC "Concern Stirol”, PrAT “Sievierodonetske Obiednannia Azot”.

The base industry of Donbas economy remains the coal industry. Donetsk region provided for Ukraine $43 \%$ of the total volume of coal mining and two-thirds - coking coal. In Luhansk region, more than $30 \%$ of all coal in Ukraine was mined. In 2012, the aggregate share of Donetsk and Luhansk regions was $78,5 \%$ of the total coal production in Ukraine, in $2013-76,6 \%$, in May $2014-76,1 \%$. The share of Donetsk region in the sale of goods of the extractive industry in 2013th was $24,1 \%$, Luhansk - 8,4\%. Industrial reserves of Donbas coal 3,4 billion tons would be enough for more than 100 years.

Nevertheless, it was the coal industry that became one of the most damaged and damaged industries in Donbas, which led to the unstable operation of the electric power industry, the metallurgical industry, coke chemistry, and utilities, and rising energy prices.

InDonetsk region, due to the instability of the situation, work was stopped at seven state mines: "Makiivvuhillia", "Artemvuhillia", "Ordzhonikidzevuhillia", "Shakhterskantratsit”, “Torezantratsit”, Donbas Mine Management, "Mospinska" Mine and 13 private coal mining enterprises. PJSC "Krasnodonvuhillia"; State Enterprise "Donbasantratsit"; SE "Anthracite"; SE "Luhanskvuhillia" has already stopped working in Luhansk region.

On the territory under the control of the Ukrainian authorities work:

1. Among the metallurgical enterprises continue their work: "Azovstal" and Ilyich Iron and Steel Works.

2. Among the machine-building enterprises continue their work: "Novokramatorsk Machine-Building Plant", "Electromashspetsstal”, "Kramatorsk Heavy Machine Tool Building Plant", "Starokramatorsky Machine Building Plant”, “Azovmash”.

In the occupied territory, controlled by terrorists continued to work "by a special scheme" until March 2017, Donbas's heavy industry plants, whose owners 
formally re-registered them on Ukrainian territory. In fact, these enterprises pay both taxes to the budget of Ukraine, and they give $20 \%$ of the profits in DNR: Donetsk Metallurgical Plant, Donetsk State Plant, Yenakiieve Iron and Steel Works, Makiivka Branch of Yenakiieve Iron and Steel Works, Khartsyzsk Pipe Plant, Dokuchaevsk Flux-Dolomite Plant, LLC “Electrostal”.

Another reason for stopping key enterprises in Donbas industry, apart from the ongoing hostilities, was the lack of sales markets for manufactured products. Namely, to date, in view of the aggravation of the conflict, the Russian market is actually lost to the Ukrainian producers, on the way to the European alternative, there are many obstacles in the form of standards and brands. For example, the prospects for the reorientation of Ukrainian exports of metallurgical and engineering products to the EU market are complicated by the lack of compliance of a significant part of it with European standards for this product, as well as the unsatisfactory environmental characteristics of such a production. Existing capabilities of the domestic market of metal products are estimated by experts as much as 10-11 million tons, which is almost three times less than in export volumes. Despite the fact that in Ukraine since 2013 there are 43 technical regulations developed on the basis of the relevant EU directives, the degree of implementation of European standards in Ukrainian enterprises remains insufficient, in view of obsolete production technologies and the need to modernize production. This represents a significant threat to the future development of export industries in the conditions of the consistent closure of Russian markets.

\section{The fall in industrial output}

The fall in industrial output also became a bitter reality in the region. On the one hand, Donbas industry produced one-fourth of the total output of the state. According to the results of the pre-war 2013, the share of Donetsk region in the industrial production of Ukraine was $18,5 \%$ in money terms, Luhansk - 6,1\%, together it was $24,6 \%$. Thus, Donbas gave every fourth hryvnia of Ukraine's income, the withdrawal of which from budgetary funds inevitably led to the current economic crisis. In addition, the machine-building industry had close ties with production complexes in other regions of the country that regularly supplied components and did not just stay afloat but could also expand and modernize production (Koshla, 2015).

On the other hand, since the Soviet times, historically, the main market for machine building products of Donbas was Russia, ceased to be a partner for Ukrainian producers. However, the currency proceeds from the export of heavy industry products in Donetsk and Luhansk regions in 2013 amounted to 20\% of the total. This makes it possible to say that before the conflict every fifth dollar of Ukraine's foreign exchange stock was Donbas. In addition to the factories and territories of the occupied territories that have ceased to function in Ukraine, they had to stop their work since the beginning of the winter: Krukovka Carriage Plant; Kremenchug Steel Plant; Dniprodzerzhynsk Association "Dniprovagonmash”. Ukrainian railwaymen consumed only 5\% of their output; Dnipropetrovsk Association "Yuzhmash".

Also, until March 2017, the heavy industry plants of Donbas worked on a "special scheme" and located in the occupied territory, were lucky enough to survive and retain at least a part of the production capacity of which remained only 20\%: Donetsk Metallurgical Plant; Donetsk State Plant; Yenakiieve Iron and Steel Works; Makiivka branch of Yenakiieve Iron and Steel Works; Khartsyzsk Pipe Plant; Dokuchaevsk Flux-Dolomite Plant; LLC "Elektrostal”.

The management of these enterprises moved to unoccupied territory, officially re-registered them in Ukraine, which made it possible to pay salaries when paying taxes (including military ones). Given the complete absence of the banking system in the DNR and LNR in 2014-2015, the money of such enterprises was cashed in Ukraine and transported in cash to the occupied territories. The terrorists, in turn, took their share of this money, the so-called " $20 \%$ tax", which was transferred to the "Ministry of Taxes and Dues" of the DNR, and then the salary reached the employees. However, despite the existence of such a scheme, since October 2014, wage arrears have become a reality for employees of enterprises in the territory of the selfproclaimed republics. Earlier, (in the pre-war period, at the beginning of 2014), at Donetsk Metallurgical Plant, the average salary was 8 thousand hryvnia; the minimum salary of a labourer was 6 thousand hryvnia.

As for Ukraine, according to more than optimistic estimates of the Ministry of Energy, the decline in state coal mining in 2015 was almost 2 times, that is, up to 9 million tons, compared to 17 million tons from the already reduced in 2014. In January 2015, coal mining in Ukraine amounted to 3,42 million tons, compared to 6,933 million tons for the same period in 2014. In connection with this, state enterprises "Lvivvuhillia" and "Volynvuhillia" were auctioned for the purpose of breaking the situation in the coal industry by attracting large capital in it and saving the industry. However, in conditions of a sharp drop in the hryvnia and the growth of interest rates on bank loans from $14 \%$ to $19 \%$, and then $24 \%$, it was unreal to find the oligarch who was able to invest in such assets, especially since the coal of the Western Ukrainian deposits is higher in ash content and with lower heating value than in the Donbas, and therefore cheaper. The state is also, for a number of objective reasons connected with the conduct of hostilities in the East, unable to finance the development of these enterprises (in the state budget in 2015,2016 and 2017 was not provided the allocation of 
money for the completion of the mine "Novovolynska 10 " which is capable to supply 900 thousand tons of coal per year), and it has not enough of own funds from mines to ensure coal mining in the western region (Galickij, 2016).

Thus, in the coal mining industry of Ukraine, there was not a very healthy situation, in which such a course of events may end with a traditional option for bankrupt enterprises when "Lvivvuhillia" and "Volynvuhillia" are tried by the government to sell under the scheme created by corruptor N. Azarov. After bankruptcy, the mines will be sold at a tender with a single participant and a price reduction of up to $\$ 100$, under the investment obligations of the buyer.

Despite such a difficult situation of the coal industry, "Centrenergo" in 2014 bought coal from Ukrainian miners at a price of $840 \mathrm{UAH}$ per ton, while economic realities said that for normal - minuscule work of mines, its cost should be at least 1250 UAH per ton. But why should we pay more, Kyiv officials decided, and began to buy on the black market coal from the self-proclaimed DNR and LNR for $450 \mathrm{UAH}$ per ton. Thus, at a time when an obvious crisis was emerging in a number of industries in Ukraine, which the country could no longer cope with on its own, in the occupied territories, a number of interested persons profitably utilized the situation with their own personal pocket. The government of Ukraine did not lag behind them, having developed a brilliant scheme of legal extortion from the population for buying energy resources abroad, bypassing the Russian Federation "Roterdam Plus". So the official cost of coal, for which the consumer paid, was equal to the basic purchase price, together with the cost of transportation from the coal exchange located in the seaport of Rotterdam and amounted to 3,500 UAH per ton.

The process of decline in industrial production, which began as early as 2014, remains in 2015. In 2014, compared with the previous 2013, industrial production in Donetsk region decreased by $31,5 \%$. In the basic industries of the region, the traditional production chains "coal-coke-metal" and "coal-electric power" were broken. The volume of industrial output in Donetsk region (excluding a part of the anti-terrorist operation zone), produced in January-April 2015, decreased by 2,1 times compared to the same period in 2014 (which contained 48,3\%) (Gosstat, 2015).

In January-April 2015, compared with the same period in 2014, there was a decline in production in all major industrial sectors: production of rubber and plastic products, other non-metallic mineral products by $38,9 \%$, in engineering - by $41,0 \%$, in metallurgical production and production of finished metal products - by $42,5 \%$, in the production of coke and refined products $-2,3$ times, in mining and quarrying 2,6 times, in the production of food, beverages and tobacco products - 3.1 times in the manufacture of chemicals and chemical products - by 5 times, in light industry - by 6,8 times. In January-April 2015, the volume of ordinary coal production was 4,2 million tons, which is 8,1 million tons less, or 2,9 times less than in January-April of the previous year. The volume of coal, including shipped ordinary coal and enrichment products, decreased 3 times; for January-April 2015 it was 3,2 million tons (Ukrrudprom, 2015).

Thus, the decline in industrial production entails threatening nature, since not only indicates the termination of the work of a significant part of Donbas's industrial facilities but also the closure or suspension of the largest city-forming enterprises, which is fraught with rising unemployment in the region, as well as a significant decrease in budget revenues.

\section{Reduction of foreign exchange earnings due to falling exports}

In January-March 2015, exports of goods from Donetsk region (excluding part of the zone of the antiterrorist operation) amounted to 891,1 million US dollars, which is 2,7 times less than in January-March 2013. The main problem of the metallurgical and machine-building industries of the economy of the East of Ukraine, as well as of the entire industrial complex of the region, remained the concentration of sales markets in the Russian Federation and a small share of exports to other countries during the decades of the political crisis and military confrontation.

In January-March 2015, in comparison with JanuaryMarch of the previous year, exports to the Russian Federation decreased by 3,9 times, which until 2014 was the largest foreign trade partner of Donbas. The export of all goods to the European market in January-March 2015 also decreased by 40,9\%, compared with JanuaryMarch of the previous year. The foreign currency proceeds from export supplies of ferrous metals from Donetsk region, amounting to $\$ 708,4$ million in January-March 2015 , or $79,5 \%$ of exports of all goods, decreased 2,4 times, compared to January-March 2014.

In January-March 2015, in comparison with JanuaryMarch, 2014, exports of ferrous metal products decreased by $37,7 \%$, machine-building products - by 3,5 times, chemical products - by 6,3 times, finished food products - 13,1 times.

The result of the decline in exports of enterprises in Donbas is felt throughout Ukraine, through the reduction of foreign exchange earnings, since in the precrisis period every fifth dollar in the state treasury was earned by enterprises of the East of Ukraine. According to the data of "Metallurgprom" of Ukraine, in the first quarter of 2015, the enterprises of the metallurgical industry of the country increased the negative financial result from the usual taxation activity in $65,4 \%$ compared to the corresponding period of 2014, which amounted to 21 billion UAH. The export of Ukrainian steel products fell to $\$ 2,1$ billion, or $38,2 \%$ (Ukrrudprom, 2015). 


\section{High level of environmental hazard}

High level of environmental hazard is caused by the threat of man-made disasters of different levels that arose as a result of incorrect closures of enterprises or technological errors in emergency stop production. According to the state of the environment, Donetsk and Luhansk regions have traditionally been the most polluted regions and ranked first among other regions of Ukraine in terms of the volume of pollutants entering the atmosphere. The deterioration of the geotechnical condition of the territory, due to the closure of the mines, activates the destruction of civil and industrial structures, communication and transport systems, the violation of the hydrological regime and the raising of the groundwater level, and the flooding of areas by the mine waters. The situation is complicated by the uncontrolled nature of the process, namely, as a result of the fighting; most coal enterprises were closed without proper conservation, which led to the emergence of technical poison waters into the common water basins of the region and the country. The total complexity in Donbas is 248 mines that are depleted, not developed and pose a serious threat to environmental safety.

Under the influence of the waste waters of Donbas mines $\left(20,000 \mathrm{~m}^{3}\right.$ hourly), the mineralization of water in the rivers increased more than twice in 2014, the content of sulphates is tripled, which is detrimental to the flora and fauna of the reservoirs.

ByJanuary 2015, two-thirds of Donbas coal mines were flooded, which means a contamination of groundwater and drinking water in the entire coal basin. In particular, in Horlivka, 50 tons of mononitrochlorobenzene are located at the "Alexander-Zapad" mine, which, by its chemical characteristics, has the ability to actively react with other toxic substances. According to experts, uncontrolled flooding of mines will carry this dangerous mixture into the drinking water reservoirs of Donbas. Under the threat of poisoning are the tributaries of the Seversky Donets River, which will lead to pollution of territories not only in the East of Ukraine but also in the Rostov region, and also in the Azov Sea.

There is a serious danger of radioactive contamination of the region. At the "Yuny Kommunar" mine in Yenakiievo, in 1979, a nuclear explosion was carried out, as a result of which a capsule 29 meters in diameter was formed underground, filled with water with caesium and strontium. The adjustable drainage system maintained the capsule in a stable state. But after the commencement of hostilities, the mine "Young Communar" was abandoned, water pumping was stopped, which led to the gradual flooding and subsidence of the seams, and, therefore, jeopardized the integrity of the capsule. In this regard, it should be noted that the average horizons of this mine are connected to already flooded mines "Yenakiieve" and "Poltava".
A technogenic threat is represented by the methane gas output to the surface displaced by groundwater. So in the city of Toretsk, located in the contact zone under Ukraine's control, due to the flooding of the mines "Artem" and "Pivdenna", located in the territory of the DNR, methane gas enters the cellars of residential buildings and manufacturing plants, which periodically leads to poisoning people and provokes explosions. In addition, the groundwater level began to rise, which became completely unfit for consumption because of the entry of technical waters into them.

Also in the region, there is a high threat of chemical pollution. Only in Donetsk region, there are 6,5 thousand objects of increased man-caused danger, 2,388 of which are entered in the State Register of HighRisk Facilities, among them 174 enterprises, where dangerous chemical substances are stored $(11,7 \%$ of the national quantity). In terms of chemical risks, the greatest threat is represented by Stirol and Horlivka Chemical Plant, where 325,000 tons of hazardous wastes are stored. In Luhansk region, there are 1128 chemical hazard facilities, of which 159 are objects of increased danger (Zarovna, 2015).

A very complicated situation develops in a phenolic plant located in the grey zone between the settlements Skotovata (controlled by the DNR) and Toretsk (controlled by Ukraine), its shale-storage dam, which requires major repairs, is in the zone of constant shelling. In the event of its breakthrough, 33 thousand tons of liquid waste products containing phenol, naphthalene, formaldehyde, sulphuric acid and other petroleum products will pour into the Novhorodske settlement, Kryvyi Torets river, and from it into the Siverskyi Donets river, which are sources of drinking water for Donetsk and Luhansk regions.

Therefore, the International Committee of the Red Cross proposed the establishment of security zones, at least around the water supply facilities in Donbas. The international expert-journalistic group Bellingcat unveiled the results of its own investigation, which indicated 900 large industrial enterprises in one way or another of Donbas threatening the ecological safety of them: 140 coal mines, 40 metallurgical plants, 7 thermal power stations, and 177 chemically hazardous industries, on 113 of which radioactive materials are used.

\section{The lost industry of Donbas}

Military operations that unfolded in Donbas since May 2014, swept the most industrialized areas of Donetsk and Luhansk regions. In the conflict zone, there was a coal mining industry in the region with mines and concentrating mills and a lot of industrial enterprises whose products are of strategic importance. For the economy of Ukraine, Donbas was not only a centre for the extraction of coal, advanced metallurgy, heavy engineering, and chemical production but also 
a region where a large part of its enterprises worked for the defence industry. As practice showed in the conditions of ATO maintenance, industrial enterprises in Donetsk and Luhansk regions were threatened not only by military actions but also by a number of enterprises that manufactured products for the needs of the military during the summer and the first two months of the autumn of 2014, and were removed from our state.

To the mercy of fate were left some factories of the defence industry, the development of which is not only unique but also secret. By not exact and scattered data, enterprises in Luhansk, Donetsk, Krasnodon, and Snizhne became mining of illegal armed formations. In the list of plants where equipment was dismantled, there are eight enterprises. They are OJSC "Tochmash Plant" (Donetsk), OJSC Topaz (Donetsk), CJSC "Luhansk Cartridge Plant" (Luhansk), Luhansk Electronic Machine Building Plant "Mashzavod-100" (Luhansk), OJSC "Luhanskteplovoz" (Luhansk), Luhansk Machine Building Plant named after Parkhomenko (Luhansk), "Yunist" OJSC (Krasnodon, Luhansk Region), branch of "Motor Sich Plant" (Snizhne).

1. "Tochmash" factory (Donetsk) specializes in the production of hydraulic equipment, hydraulic cylinders, pipeline fittings, the main products of which are "Lyman Complexes" designed for the radio suppression of aviation control lines in the frequency ranges 100$400 \mathrm{MHz}$ and $960-1215 \mathrm{MHz}$. Among the owners of the plant are firms affiliated with Russian structures: AFK "Sistema" Vladimir Yevtushenko and VAB Bank Oleg Bakhmatyuk.

2. OJSC Topaz (Donetsk) is a part of the State Joint-Stock Holding Company "Topaz" (until April 2014, it was managed by the Ministry of Industrial Policy, restructured by the Ministry of A. Yatsenyuk). The plant produced complexes for radio suppression of lines and control of aviation in the frequency ranges $100-400 \mathrm{MHz}$ and $960-1215 \mathrm{~Hz}$ (of the "Liman" type), as well as modern radar stations (such as "Kolchuga"). In the system of disclosure of the State Commission for Smida, Smida does not name its customers, since the only sales channel for it is SE Ukrspetsexport (a marketing enterprise of the state enterprise "Ukroboronprom"). Over $95 \%$ of the plant's products are exported.

On September 2014, the parts of illegal armed formations exported to the territory of the Russian Federation a ready-made navigational complex "Mandate", proceeding to complete dismantling of equipment located in the enterprise. Such well-thoughtout actions by the beginning of the autumn of 2014 have borne fruit. Since already in September both DNR and LNR suddenly had an echeloned air defence system installed by specialists who had come from the Russian Federation. The basis of which lie "Liman" and radar stations of the "Kolchuga" type.
3. Joint-Stock Company "Luhansk Cartridge Plant" (Luhansk) according to the weekly "Business", its founder is the company "Bickford", which in parallel with a number of business structures such as: Kerch Shipyard "Zaliv", JSC Luhansk Machine-Tool Plant "Zaliv" is a part of the David Zhvania's property, one of the biggest sponsors of the Victor Yushchenko party "Our Ukraine". Although he claims that he has never been the owner of these enterprises, he only carried out effective management, for which he received solid fees. However, it is possible that the scandalous politician decided to save his capital by reselling the property in the occupied territories to Russian business structures. However, Zhvania did not comment on this situation.

4. Luhansk Machine-Building Plant named after Parkhomenko (Luhansk), owned by former deputy Anatoly Yagoforov, whose machines and equipment were transported to the Russian Federation. And this information was confirmed by Russian media, which published an interview with the technical consultant of the plant, Nikita Druzev, who said that the equipment of the plant was transported to Chuvashia, Cheboksary. According to him, the decision was made by the owners of the plant. The main staff of the plant "moved" together with the machines and equipment.

"The company worked for 12 years mainly in the Russian market, therefore, the business owners decided to evacuate together with the team and equipment to Russia," the report said.

5. The equipment of Luhansk Electronic Machine Building Plant "Mashzavod-100" (Luhansk) was also dismantled, where they developed and manufactured equipment for the production of single crystals of silicon, sapphire and other solid and super-hard single crystals that are components for the Motor Sich.

This information is confirmed by the words of the NSDC Speaker, Andrei Lysenko, who reported that in trucks that entered Ukrainian territory as the first humanitarian convoy, the Russians loaded the equipment of the "Topaz" production association, which is engaged in the production of radar stations and equipment of Luhansk Machine-Building Plant named after Parkhomenko, producing cartridges for small arms.

6. OJSC "Yunist" (Krasnodon, Luhansk region) specializing primarily in the production of various types of relays, $94,6 \%$ of whose shares belonged to the state of Ukraine and were managed by the State Property Fund. The company produced highly stable, highly accurate microminiature sealed relays weighing from 2 grams for special equipment of aviation, aerospace, missile industry. The plant was a monopolist in the CIS for the production of low-voltage unpolarized relays of RES 79, RES 80, RPS 42, RPS 43 REK 21 - for special equipment for the aviation, aerospace, missile industry; automotive relays for electrical equipment of cars, trucks, passenger vehicles, agricultural machinery. The company "Yunist" was a monopolist not only among the 
CIS countries but throughout Europe, in the production of specialized products for the rocket and aerospace industry, in particular, the supply of microchips used in the construction of missiles and submarines. Just before the beginning of the ATO, the plant supplied high-precision Japanese equipment. The bulk of products were exported to Russia, the customers were enterprises of the defence industry complex. "Youth", as well as "Topaz", belonged to the same Ministry of Industrial Policy of Ukraine, which was so successfully restructured. And consequently, the situation with the loss for the Ukrainian defence industry of this enterprise is similar to the situation with OJSC "Topaz" - it was also exported to Russia with all equipment.

7. «Luhanskteplovoz» (Luhansk) as a result of active privatization policy of L. Kuchma in 2001, the assets of the plant were sold to Russian "Transmashholding". The competitor at the auction was none other than Igor Kolomoisky. The state initiated the sale of $76 \%$ of the company's shares. True, I. Kolomoisky tried to find out the relationship with the rival in court, as a result, only in 2010, "Transmashholding" was finally lucky to become a full owner of the enterprise. Military operations in the East of Ukraine for many representatives of big capital can be a reason for selling their assets to Russia, so that the enemy will be able to get the most promising Ukrainian capacities, not only from the military but also from the civilian sector.

8. Such information appeared in relation to one of the branches of "Motor Sich" (Snizhne, Donetsk region), which produced blades and disks for turbines of jet and turbojet engines of aircraft and helicopters, was also the only one in the post-Soviet space, which technology allowed the production of blades for turbines with built-in crystals (the cost of one turbine is equal to the cost of a German foreign car of the last model). The use of these technologies makes it possible to avoid overheating of turbines at excess speeds and increases engine power when speed is set to the limit. In addition, the export of the enterprise to Russia was also interesting in the context of obtaining equipment for the manufacture of components for the engines of Russian helicopters.

\section{Conclusions}

The information on exportation above the abovementioned enterprises was confirmed by the data of the Main Command Centre of the Ministry of Defence of Ukraine, in which it was reported that the militants, in cooperation with Russian customers, had dismantled the equipment of strategic enterprises of the militaryindustrial complex.

Thus, in the transfer of a controlling stake in strategically important industrial enterprises of Donbas defence complex, the representatives of Russian capital can clearly see the hand of no President of Ukraine. Not a few efforts to deliver innovative technologies in the defence industry were made by the so-called "young reformers" of modern days who simply closed their eyes, and dismantled and removed equipment outside Ukraine. So we can say with complete certainty that the collapse of the industrial enterprises of the military complex of the East of Ukraine was planned long before the start of the military-political conflict, and it is obvious that not only the domestic oligarchs succeeded in implementing these grandiose plans.

To this day it remains a mystery why the authorities, who know about the strategic military importance of these enterprises and the uniqueness of their developments, did not bother to evacuate in a timely manner either enterprises, production documents or specialists. Perhaps there was a moment of underestimation of the enemy's forces and capabilities, or there was a deliberate surrender of the giants of the defence industry.

\section{References:}

Vosstanovit Donbass: missija nevypolnima! Retrieved October 20, 2015 from: http://ord-02.com/item/51999vosstanovit-donbass-missiya-nevyipolnima

Galickij A. (2016). Kak izmenilsja ugol'nyj rynok Ukrainy v 2016 godu. Retrieved October 20, 2016 from: https: / / delo.ua/business/kak-izmenilsja-ugolnyj-rynok-ukrainy-v-2016-godu-323757/

Gosstat. Za 2015 g. ukrainskaja promyshlennost upala na 13,4 \%. Retrieved January 21, 2016 from: http:// gordonua.com/news/money/gosstat-za-2015-god-ukrainskaya-promyshlennost-upala-na-134--116418.html

Zarovna T. (2015). 5 ekolohichnykh bomb Donbasu, yaki mozhut zdetonuvaty pid chas viyny. Retrieved June 24, 2015 from: https://www.obozrevatel.com/ukr/crime/53904-5-ekologicheskih-bomb-donbassa-kotoryie-mogutsdetonirovat-vo-vremya-vojnyi.htm

Koshla V. (2015). A nuzhen li Donbass? Retrieved April 2, 2015 from: http://avesta.tj/2015/04/02/a-nuzhen-lidonbass-2/

Ukrrudprom. Promyshlennoe proizvodstvo Doneckoj oblasti za janvar-aprel 2015 goda sokratilos v 2,1 raza. Retrieved March 20, 2016 from: http://www.ukrrudprom.ua/digest/ Promishlennoe_proizvodstvo_Donetskoy_ oblasti_za_yanvaraprel_2015_goda_sokratilos_v_21_raza.html 


\section{Елена КЛИМЕНКО}

\section{АНАЛИЗ СОСТОЯНИЯ ВЕДУЩИХ ОТРАСЛЕЙ ЭКОНОМИКИ ДЛЯ СТАРОПРОМЫШЛЕННОГО РЕГИОНА ДОНБАССА - ЛЕТО-ОСЕНЬ 2014 ГОДА}

Аннотация. Целью статьи является изучение состояние регионального промышленного комплекса старопромышленного региона Востока Украины пострадавшего в результате военно-политического конфликта начавшегося в 2014 году. Одной иззадач исследования является анализ процесса разрушения основ региональной экономики, а также оценка значения утраты отраслей Донбасса для стабильного социальноэкономического развития всех регионов Украины. Методика исследования. Метод анализа позволил изучить процесс разрушения промышленных предприятий базовых секторов региональной экономики Донбасса с начала военно-политического конфликта. Автором определены схемы функционирования части предприятий, работающих на временно оккупированной территории Востока Украины, которые, став заложниками ситуации, для сохранения производства вынуждены были сотрудничать с представителями незаконных властей непризнанных республик. Статистический метод использован для анализа финансовых и экономических показателей предприятий промышленного комплекса, с целью проведения оценки их роли в государственной экономике страны в целом. Метод системного анализа позволил автору оценить, ущерб от утраты в экономике государства поставок угля, который ранее добывался на шахтах Донбасса. Таким образом, был аргументирован факт уменьшения промышленного производства на востоке страны, что привело к существенному падению экспорта Украины в целом по таким направлениям как: поставки черных металлов, продукции машиностроения и цветной металлургии. Практические результаты работы. Автором проанализированы факты утраты, в результате демонтажа и вывоза оборудования, стратегически важных предприятий военно-промышленного комплекса страны. В статье отражена проблема возрастающей экологической опасности, возникшей в результате отсутствия контроля над закрытыми предприятиями угледобывающей отрасли и химической промышленности. Кроме того, в ходе активных боевых действий ряду объектов промышленности были нанесены значительные повреждения, что приводит к неконтролируемым выбросам в атмосферу вредных веществ. Остановка шахт и обогатительных фабрик создала еще одну проблему -сброс шахтныхвод, их выход на поверхность, подтопление значительных территорий и попадание ядовитых токсичных вод в реки, служащие источником питьевой воды для жителей, как региона конфликта и страны в целом, так и соседних государств. Также техногенную угрозу представляет и выход газа метана на поверхность, вытесняемого грунтовыми водами. Оригинальность проведенного исследования заключается в демонстрации динамики разрушения экономического комплекса старопромышленного региона в следствии ведения боевых действий на территории государства и незаконного вывоза оборудования предприятий. Все эти действия привели к запуску негативных процессов в украинской экономике, спровоцировав глубокий социально-экономический кризис, что ускорило разрушение металлургической, угольной и химической отраслей региона. Таким образом, сегодня необходимо проводить инвентаризацию уцелевших и продолжающих работать предприятий, оперативно определять зону рисков и разрабатывать стратегии их минимизации и преодоления в ключевых отраслях экономики. 